\title{
Observation: Life history of spotted knapweed
}

\author{
JAMES S. JACOBS AND ROGER L. SHELEY
}

Authors are post-doctoral research associate and assistant professor, Department of Plant, Soil and Environmental Sciences, Montana State University, Bozeman, Mont. 59717.

\begin{abstract}
Spotted knapweed (Centaurea maculosa Lam.) is a non-indigenous weed infesting large areas of rangeland in western North America. Life history models have been used to identify key processes regulating weed population dynamics and may be valuable in developing and testing integrated weed management strategies. Our objective was to characterize the life history of spotted knapweed. Demographic attributes were monitored monthly during snow free periods beginning August 1994 through October 1996 on 2 sites. Data were arranged into life history tables, and sensitivity analysis was performed to determine key transition phases affecting seed output. Spotted knapweed seed production ranged from 998 to 7815 viable seeds $/ \mathrm{m}^{2}$ at both sites during the study. Seeds reaching the soil averaged $\mathbf{4 1}$ and $50 \%$ of seed output at sites 1 and 2 , respectively. Less than $6 \%$ of seeds reaching the soil germinated in the fall at both sites. Recruitment peaked in April at $36 \%$ and in June at $20 \%$ of seeds reaching the soil on sites 1 and 2, respectively. Spotted knapweed juvenile density peaked August 1995 and June 1996 at both sites. Peaks corresponded with the beginning of the summer dry period. Plants bolted beginning June 1995 and May 1996. Sensitivity analysis identified early-summer juvenile survivorship, late-summer adult survivorship, transition from juvenile to adult, and seeds produced per adult as critical stages for spotted knapweed seed output. Management strategies that reduce spotted knapweed populations at these stages are likely to have the greatest impact on spotted knapweed population growth and spread. A weed population dynamics model using the life history demographic data was developed and can be used to design and test integrated spotted knapweed strategies.
\end{abstract}

Key Words: noxious weed, weed demography, weed population dynamics, simulation model

Spotted knapweed (Centaurea maculosa Lam.) is a deeply taprooted Eurasian perennial weed invading rangeland in the western United States and Canada. It is currently reported in 326 counties within 15 western states, including every county in Washington, Idaho, Wyoming and Montana (Sheley et al. 1998). Large-scale monotypic infestations of spotted knapweed can reduce livestock and wildlife forage (Watson and Renney 1974), reduce plant diversity (Tyser and Key 1988), and increase surface

\footnotetext{
Published with the approval of the director, Montana Agricultural Experiment Station, as Journal No. J-5132.
}

Manuscript accepted 30 Nov. 1997

\section{Resumen}

Knapweed manchado (Centaurea maculosa Lam.) es una maleza no -indigena que infesta grandes zonas de praderas en el oeste de Norte-américa. Modelos del ciclo de vida se han usado para identificar los procesos claves que regulan las dinámicas de la población de esta maleza, y los modelos pueden ser útiles para desarrollar y poner a prueba estrategias integradas de control de esta maleza. Nuestro objetivo fué caracterizar el ciclo la vida del knapweed manchado. Atributos demográficos fueron anotados mensualmente en dos sitios durante las épocas sin nieve empezando en Agosto de 1994, hasta Octubre de 1996. Los datos fueron arreglados en tablas representando el ciclo de vida y se ejecutó un análisis de sensibilidad para determinar las fases claves de transición que influyen en la producción de semillas. La producción de semillas del knapweed manchado varió entre 998 hasta 7815 semillas viables $/ \mathrm{m}^{2}$ en los dos sitios durante el estudio. Las semillas que llegaron hasta el suelo fueron de un promedio de $41 \%$ y de $50 \%$ de la producción total en los sitios I y 2 respectivamente. Menos de $6 \%$ de las semillas que llegaron al suelo germinó en el otoño, en ambos sitios. El establecimiento alcanzó el punto más alto en Abril a $36 \%$ y en Junio a $20 \%$ de las semillas llegando al suelo en los sitios 1 y 2 respectivamente. La densidad de las plantas juveniles del knapweed manchado llegó al punto más alto en Agosto de 1995 y en Junio de 1996 en ambos sitios. Los puntos más altos correspondieron con el principio de la época seca estival. Las plantas produjeron tallos floridos empezando en Junio de 1995 y en Mayo de 1996. El análisis de sensibilidad identificó como etapas criticas para la producción de las semillas del knapweed manchado: la sobrevivencia juvenil del verano-temprano, la sobrevivencia adulta del verano tardio, la transición de juvenil a adulto y las semillas producidas por los adultos. Es probable que las estrategias de control que reduzcan las poblaciones del knapweed manchado en estas etapas tengan el impacto más fuerte en el crecimiento y difusión de la població n del knapweed manchado. Un modelo de las dinámicas de la población de la maleza se desarrolló usando los datos demográficos del ciclo de vida y se puede usar para diseñar y poner a prueba estrategias integradas de control del knapweed manchado.

water run-off, soil erosion, and stream sedimentation (Lacey et al. 1989). High seed output and seed longevity make long-term control of spotted knapweed difficult and expensive because seedlings emerge after herbicides dissipate or leach into the soil (Shirman 1981, Griffith and Lacey 1991, Davis et al. 1993).

To minimize arbitrary weed management decisions, rangeland managers need to develop conceptual models of weed management that predict plant community composition based on the 
existing plant community and the weed management strategy (Sheley et al. 1996). Cropping systems ecologists use bioeconomic models to calculate economic thresholds based on crop/weed interference and empirically-derived demographic data from life history studies (Barton et al. 1992, Maxwell 1993, Dunan et al. 1994, Swinton and King 1994, Lindquist et al. 1995). Life history data from Sheley and Larson (1994) were used to develop a model to predict the population dynamics of yellow starthistle (Centaurea solstitialis L.)(Maxwell and Sheley 1997). Life history data have also been the basis of a model used to identify key processes of vegetation change and to calculate probabilities and timespans for transitions between vegetation stages in management of semiarid plant communities (Wiegand and Milton 1996).

Whether evaluating economic and environmental costs of conventional chemical weed control, assessing various unconventional alternatives, or developing and investigating the feasibility of integrated noxious weed management strategies, the need for ecologically-based, realistic, predictive models is substantial and unmet. The objective of this study was to use the method developed by Sagar and Mortimer (1976) to characterize the life history of spotted knapweed. Sensitivity analysis was conducted on the life history model to determine key processes related to seed output, and population and community regulation. Data were used to reparameterize the life history model developed by Maxwell and Sheley (1997).

\section{Materials and Methods}

\section{Study Site and Sampling Procedures}

The study was conducted on 2 sites, each with 10 randomly placed $2 \mathrm{~m}^{2}$ permanent sampling plots. Both sites lie within an Idaho fescue (Festuca idahoensis Elmer)-bluebunch wheatgrass (Agropyron spicatum (Pursh) Scribn. \& Smith) habitat type (Muegller and Stewart 1980) dominated by spotted knapweed. Site 1 was $10 \mathrm{~km}$ west of Bozeman, Mont. (111 ${ }^{\circ} 5^{\prime} 36^{\prime \prime} \mathrm{W}, 45^{\circ}$ $36^{\prime} 26^{\prime \prime} \mathrm{N}$ ) on an abandoned hay meadow. The soil was a complex consisting of $70 \%$ Beaverton cobbly loam (Loamy-skeletal over sandy-skeletal, mixed, Typic Argiborolls) and 30\% Hylite loam (Fine-loamy, mixed, Typic Argiborolls). The residual grass understory consisted of Kentucky bluegrass (Poa pratensis L.), smooth bromegrass (Bromus inermis Leys), and timothy (Phleum pratense L.). It had a zero slope and an elevation of $1,340 \mathrm{~m}$. Neither Idaho fescue nor bluebunch wheatgrass were present. Average annual ( 60 year) precipitation is $350 \mathrm{~mm}$ with a bimodal distribution with peaks in autumn and spring (NOAA 1994, 1995, and 1996). Temperatures range from $36^{\circ}$ to $-35^{\circ} \mathrm{C}$ with a frost free season of 90 days.

Site 2 was located $15 \mathrm{~km}$ northwest of Bozeman, Mont. The soil, a Bavdark loam (Fine-loamy, mixed Argic Pachic Cryoboroll) had a 10 to $20 \%$ northwesterly slope and $1,400 \mathrm{~m}$ elevation. Residual understory grasses were predominantly Idaho fescue with some bluebunch wheatgrass, onespike oatgrass (Danthonia unispicata (Thurb.) Munro ex Macoun) and timothy. Average annual (60 year) precipitation is $450 \mathrm{~mm}$ with a bimodal distribution with peaks in autumn and spring (NOAA 1994, 1995, and 1996). Temperatures range from $35^{\circ}$ to $-31^{\circ} \mathrm{C}$ with a frost free season of 60 days. Temperature and precipitation were monitored daily at 2 weather stations, 1 near each site, and summarized for each month.
The life history of spotted knapweed was monitored during snow-free periods from August 1994 to October 1996 at monthly intervals. This included 3 seed-producing generations. At each sampling date, data were collected and characterized as seed out$\mathrm{put} / \mathrm{m}^{2}$, monthly seed rain $/ \mathrm{m}^{2}$ upon the soil surface, accumulated seed rain $/ \mathrm{m}^{2}$ upon the soil surface, seedlings $/ \mathrm{m}^{2}$ (1-5 leaves), juveniles $/ \mathrm{m}^{2}$ ( 6 leaves to initiation of flower head), and adults $/ \mathrm{m}^{2}$ (initiation of flower head to maturity).

Soil seed bank was estimated in 1994 and 1995 by sifting (2mm sieve) 50 randomly located soil samples collected from around the permanent plots before seed drop. Each sample contained $221 \mathrm{~cm}^{3}$ soil from the top $80 \mathrm{~mm}$ of the soil profile. All intact spotted knapweed seeds were counted and tested for viability using tetrazolium staining (Garbe 1970). Deteriorated and unfilled seeds were recorded.

Seed rain upon the soil surface was estimated using a variation of the sticky trap discussed by Huenneke and Graham (1987). Fifty wooden traps $(38 \mathrm{~mm} \times 100 \mathrm{~mm})$ were coated with a smooth surface of lithium-based grease and randomly placed flush on the soil surface within and around the permanent plots. Spotted knapweed seeds were counted at each sampling to estimate seed rain. Traps were then cleaned and grease was reapplied. Accumulated seed rain was calculated by summing prior seed rain counts.

Densities of spotted knapweed seedlings, juveniles, and adults were determined by counting individuals in $1 \mathrm{~m} \times 1 \mathrm{~m}$ frames located within each permanent plot at each site. Grass densities were determincd by counting tillers in each frame.

Spotted knapweed seed production was estimated by counting the number of seed heads on 5 individual adults randomly selected within each permanent plot. Fifty seed heads were randomly collected from plants growing within an area with a $100 \mathrm{~cm}$ radius from the outer edge of each permanent plot so as not to affect the seed rain within the plot. The number of seeds per head was counted. Seed production per plant was calculated by multiplying the number of seeds per head by the number of seed heads per plant. Seed viability was tested using tetrazolium staining (Garbe 1970).

\section{Analysis}

A 95\% confidence interval for the mean of each demographic parameter at each sampling date was calculated using the standard error about the mean. Models were developed by arranging data into life history tables (Sagar and Mortimer 1976). Each transition parameter was calculated as the percent change from one sampling date and/or life history stage to the next. It was assumed that during periods of population decline, transitions from one growth stage to the next did not occur, and that mortality constituted the decline. Conversely, it was assumed that during periods of population increase that all individuals within a stage survived to the next sampling date. These assumptions are supported by the observations of Sheley and Larson (1994) for yellow starthistle populations.

A $10 \%$ sensitivity analysis was calculated on the life history model (Maxwell et al. 1988). Transitions with the highest sensitivity values have the greatest effect on determining seed output (Sheley and Larson 1994). Proccsses associated with the transition parameters with the highest sensitivity values were considered most important. The effect of $10 \%$ reductions on seed output was defined as: 
Sensitivity value $=\underset{\text { Seed output }}{\Delta \text { seed outpul }} / \frac{\Delta \text { transition parameter }}{\text { Transition parameter }}$

\section{Model Development}

Life history data from each site and year wcrc averaged and used to reparameterize the demographic data in the noxious weed population dynamics model developed by Maxwell and Sheley (1997) (Table 1). Reparameterization involved changing the life history stages (state variables) of spring and fall seed banks, spring and fall seedlings, rosettes, flowering plants, and seeds produced which return to the fall seed bank (Fig. 1). Reparameterization of the demographic processes which regulate the rate of transition between state variables over a 1 year period included: fall and spring germination, summer and winter mortality and transition to flowering plants, flowering plant seed production and winter mortality, and seed migration away from the population. The model is capable of including density dependent population regulation, stochastic variation, biological control impacts, and impacts of a seeded competitive grass (Maxwell and Sheley 1997), however only density dependent population regulation was used to predict the spotted knapweed rosette and adult population dynamics for 20 generations.

\section{Results}

\section{Temperature and Precipitation}

Monthly precipitation at both sites in 1994 showed a typical bimodal distribution with peaks in spring and fall (Table 2). May precipitation was below average by about $50 \mathrm{~mm}$, and above average in July by about $35 \mathrm{~mm}$. In 1995, precipitation was below average in May $(40 \mathrm{~mm})$ and June $(13 \mathrm{~mm})$ and above average during July by about $35 \mathrm{~mm}$, and August by about $30 \mathrm{~mm}$ at each site. In 1996, May precipitation was also above average by about $30 \mathrm{~mm}$, but was below average during June, July, August, and September by average of $30 \mathrm{~mm}$ per month at each site.

\section{Life History}

At Site 1 in 1994, there were 99 aduits $/ \mathrm{m}^{2}$, which produced 21 seeds per individual, $60 \%$ of which were viable, for an approximate viable seed output of 1,237 seeds $/ \mathrm{m}^{2}$ (Fig. 2). In 1995, the adult spotted knapweed population was 10 individuals $/ \mathrm{m}^{2}$. Adults

Table 1. Model parameter descriptions and spotted knapweed values used for reparameterization.

\begin{tabular}{ll}
\hline \hline Parameter Description & Value \\
\hline Fall seed bank (SBf) & 4260 \\
Spring germination rate (grms) & 0.146 \\
Fall germination rate (grmf) & 0.031 \\
Seed mortality rate over winter (smw) & 0.73 \\
Seedling mortality rate during spring (sdms) & 0.068 \\
Seedling mortality rate during fall (sdmf) & 0.725 \\
Rosette mortality rate over winter (rm) & 0.483 \\
Rosette to flowering plant transition rate (flw) & 0.267 \\
Mature (flowering plant) mortality over winter (mpm) & 0.455 \\
Seed produced per plant (sppw) & 62 \\
Proportion of sccd rain that migratcs away (mr) & 0.568 \\
Max. seed produced/plant with no interference (spmaxw) & 8000 \\
\hline
\end{tabular}

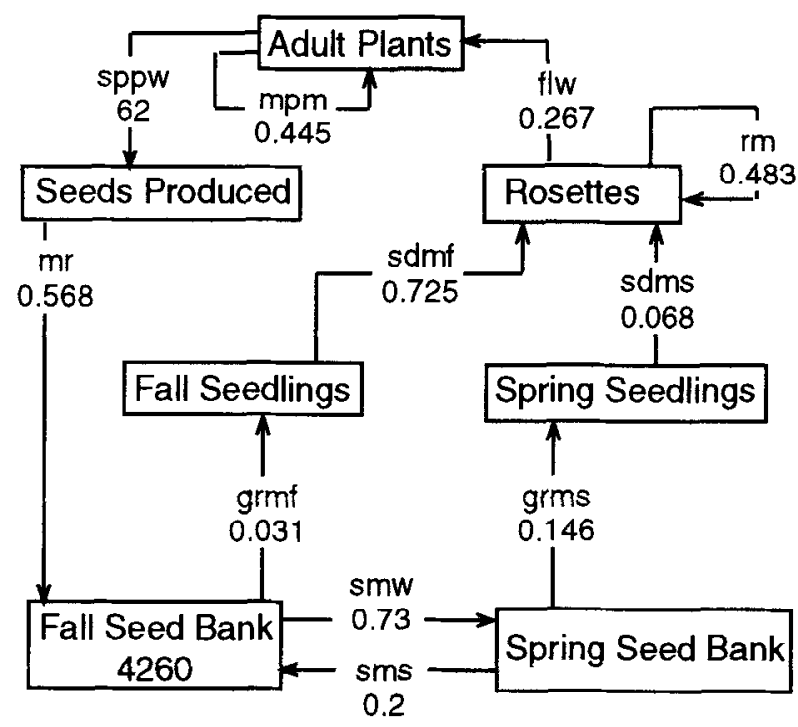

Fig. 1. Life history model of a spotted knapweed population showing states (boxes) and transitions (arrows) throughout its life history for each population. Processes are described in Table 2.

produced 140 seeds per individual, of which $71 \%$ were viable, for an approximate viable seed output of $998 / \mathrm{m}^{2}$. The 1996 spotted knapweed population produced 54 adults $/ \mathrm{m}^{2}$. Adults produced 61 seeds per individual, of which $79 \%$ were viable, for an estimated viable seed output of 2617 seeds $/ \mathrm{m}^{2}$.

At Site 2 in 1994 there were 177 adults $/ \mathrm{m}^{2}$ each with 62 seeds per individual, $71 \%$ of which were viable, for an approximate viable seed output of 7,815 seeds $/ \mathrm{m}^{2}$ (Fig. 3). In 1995, 151 adults $/ \mathrm{m}^{2}$ produced 55 seeds per individual with $82 \%$ viability, for an approximate viable seed output of $6,986 \mathrm{seeds} / \mathrm{m}^{2}$. In 1996 , 89 adults $/ \mathrm{m}^{2}$ produced 51 seeds per individual for an approximate viable seed output of 3,529 seeds $/ \mathrm{m}^{2}$.

The spotted knapweed seed bank at Site 1 was $51,850 \pm 30,600$ seeds $/ \mathrm{m}^{2}$ in 1994 and $47,000 \pm 7,900 \mathrm{seeds} / \mathrm{m}^{2}$ in 1995 . Based on tetrazolium tests, the number of viable seeds were $3,825 \pm 1,285$ seeds $/ \mathrm{m}^{2}$ and $34 \pm 43$ seeds $/ \mathrm{m}^{2}$ in 1994 and 1995, respectively, indicating that most seeds collected were cither unfilled or decomposed. At Site 2, the spotted knapweed seed bank was $60,690 \pm 13,133 \mathrm{seeds} / \mathrm{m}^{2}$ in 1994 and $60,350 \pm 13,023 \mathrm{seeds} / \mathrm{m}^{2}$ in 1995. Based on tetrazolium tests, the numbers of viable seeds were $8,466 \pm 3,060 \mathrm{seeds} / \mathrm{m}^{2}$ and $646 \pm 850 \mathrm{seeds} / \mathrm{m}^{2}$ in 1994 and 1995 , respectively.

Seed rain at both sites occurred during August and September. By October at Site 1, 46\% (573 seeds $\left./ \mathrm{m}^{2}\right), 47 \%$ (480 seeds $\left./ \mathrm{m}^{2}\right)$, and $30 \%\left(600\right.$ seeds $\left./ \mathrm{m}^{2}\right)$ of the seeds produced reached the soil surface of the plots in 1994, 1995, and 1996, respectively. At Site $2,56 \%\left(4,414\right.$ seeds $\left./ \mathrm{m}^{2}\right), 62 \%\left(4,355\right.$ seeds $\left./ \mathrm{m}^{2}\right)$, and $33 \%(1,155$ seeds $/ \mathrm{m}^{2}$ ) of the seed produced reached the soil surface by October 1994, 1995, and 1996, respectively.

Fall seedling recruitment at Site 1 was observed by October each year. Less than $1 \%$ and $3 \%$ of the seed rain produced seedlings in the fall of 1994 and 1995, respectively. In 1995, seedling recruitment peaked at 201 seedlings $/ \mathrm{m}^{2}$ by April and continued through June. Thirty-six percent of the seed rain was recruited into the seedling population that year. In 1996, seedling recruitment peaked by June at 92 seedlings $/ \mathrm{m}^{2}$. There was no 
Table 2. Temperature and precipitation from 2 weather stations near the 2 spotted knapweed life history sites. M denotes missing data.

\begin{tabular}{|c|c|c|c|c|c|c|c|c|}
\hline \multirow[t]{2}{*}{ Month-year } & \multicolumn{2}{|c|}{ Precip } & \multicolumn{2}{|c|}{ Average } & \multicolumn{2}{|c|}{ Min } & \multicolumn{2}{|c|}{ Max } \\
\hline & Site 1 & Site 2 & Site 1 & Site 2 & Site 1 & Site 2 & Site l & Site \\
\hline & \multicolumn{2}{|c|}{$(\mathrm{mm})$} & \multicolumn{4}{|c|}{$\left({ }^{\circ} \mathrm{C}\right)$} & & \\
\hline Jan. 94 & 5 & 9 & 0.3 & 0.3 & -18.3 & -16.7 & 12.2 & 12.8 \\
\hline Feb. 94 & 11 & 23 & -4.2 & -3.9 & -29.5 & -28.9 & 13.9 & 13.9 \\
\hline Mar. 94 & 22 & 21 & 3.7 & 4.3 & -12.8 & -10.6 & 22.8 & 22.2 \\
\hline Ap.r 94 & 38 & 35 & 7.1 & 7.8 & -8.9 & -12.8 & 27.2 & 26.1 \\
\hline May 94 & 37 & 37 & 12.9 & 13.5 & 0.6 & -0.6 & 27.8 & 27.2 \\
\hline Jun. 94 & 84 & 89 & 15.2 & 16.2 & -0.6 & 0.6 & 32.2 & 31.1 \\
\hline Jul. 94 & 58 & 72 & 18.2 & 19.7 & 2.2 & 4.4 & 33.9 & 33.9 \\
\hline Aug. 94 & 13 & 15 & 19.5 & 20.6 & 4.4 & 5.0 & 35.0 & 35.0 \\
\hline Sep. 94 & 4 & 25 & 14.9 & 16.3 & -2.2 & 0.6 & 33.9 & 32.8 \\
\hline Oct. 94 & 59 & 74 & 6.4 & 6.9 & -8.32 & -7.2 & 23.4 & 22.2 \\
\hline Nov. 94 & 24 & 43 & -5.0 & -2.1 & -23.4 & -18.3 & 13.9 & 13.9 \\
\hline Dec. 94 & 16 & 18 & -4.0 & -2.8 & -20.0 & -17.8 & 10.0 & 11.1 \\
\hline Jan. 95 & 32 & 51 & -4.7 & -4.3 & -27.2 & -25 & 12.8 & 11.12 \\
\hline Feb. 95 & 56 & 11 & 0.4 & 0.16 & -25.0 & -23.4 & 17.8 & 17.2 \\
\hline Mar. 95 & 44 & 55 & 0.9 & 1.2 & -20.6 & -17.8 & 16.1 & 17.2 \\
\hline Apr. 95 & 41 & 70 & 4.9 & 5.5 & -6.7 & -6.7 & 20.6 & 2.6 \\
\hline May 95 & 76 & 68 & 9.7 & 9.9 & -3.3 & -5.6 & 26.7 & 25.6 \\
\hline Jun. 95 & 43 & 47 & 13.8 & 15.1 & -1.1 & 0.00 & 30.0 & 31.1 \\
\hline Jul. 95 & 62 & 72 & 18.0 & 19.5 & 3.9 & 5.6 & 34.5 & 35.0 \\
\hline Aug. 95 & 67 & 67 & 17.4 & 19.6 & 1.7 & 3.3 & 33.4 & 34.5 \\
\hline Sep. 95 & 27 & $\mathbf{M}$ & 12.8 & $\mathbf{M}$ & -5.6 & M & 32.2 & $\mathbf{M}$ \\
\hline Oct. 95 & 39 & 6 & 5.8 & $\mathbf{M}$ & -11.1 & -9.5 & 22.2 & 21.1 \\
\hline Nov. 95 & 22 & 31 & 2.7 & 2.8 & -16.7 & -15.6 & 17.2 & 15.6 \\
\hline Dec. 95 & 19 & 15 & -2.7 & -2.3 & -25.0 & -13.4 & 15.6 & 15,36 \\
\hline Jan. 96 & 13 & 20 & -6.8 & -6.3 & -31.7 & -28.9 & 11.7 & 12.8 \\
\hline Feb, 96 & 25 & 26 & -2.9 & -2.9 & -35 & -31.1 & 14.5 & 15.0 \\
\hline Mar. 96 & 12 & 18 & -1.3 & -13.3 & -21.7 & -20.6 & 15.6 & 16.7 \\
\hline Apr. 96 & 31 & 43 & 7.6 & 7.4 & -4.4 & -3.9 & 25.6 & 25.0 \\
\hline May 96 & 115 & 112 & 8.6 & 8.7 & -4.4 & -2.2 & 21.7 & 21.1 \\
\hline Jun. 96 & 21 & 26 & 16.1 & 16.7 & -1.1 & 0.6 & 31.7 & 20.6 \\
\hline Jul. 96 & 2 & 8 & 19.8 & 19.9 & 6.1 & 7.2 & 36.1 & 34.5 \\
\hline Aug. 96 & 3 & 18 & 18.9 & 20.2 & 0.6 & 4.4 & 35.6 & 34.5 \\
\hline Sep. 96 & 28 & 27 & 11.8 & 13.2 & -3.3 & -3.3 & 30.0 & 31.1 \\
\hline
\end{tabular}

recruitment after the first of June in 1996. Forty-two percent of the seed rain was recruited into the seedling population in 1996. At Site 2, fall seedling recruitment was observed by October in 1994 and by September in 1995. Less than $1 \%$ and $6 \%$ of the seed rain produced seedlings in the falls of 1994 and 1995 , respectively. Seedling recruitment peaked at 901 seedlings $/ \mathrm{m}^{2}$ by June 1995. Twenty percent of the seed rain was recruited into the seedling population in 1995. In 1996, seedling recruitment peaked by May at 1,293 seedlings $/ \mathrm{m}^{2}$. There was no seedling recruitment after May 1996. Thirty percent of the seed rain was recruited into the seedling population in 1996 . Seedling mortality occurred from June through August 1995 and May through September 1996.

At Site 1, 22 and 97 spotted knapweed juveniles had developed from root crowns by April 1995 and 1996, respectively. In 1995, $11 \%$ of the previous year's juveniles and adults survived to form juveniles, while $97 \%$ survived in 1996. Juvenile populations peaked in August 1995 (193 juveniles/m²) and in June 1996 (202 juveniles $/ \mathrm{m}^{2}$ ). At Site 2, 146 and 278 spotted knapweed juveniles had developed from root crowns by April 1995 and 1996, respectively. In $1995,61 \%$ of the previous year's juveniles and adults survived the winter as root crowns to form juveniles, while $48 \%$ survived in 1996. Juvenile populations peaked in August (603 juveniles $/ \mathrm{m}^{2}$ ) and June (692 juveniles/m²) in 1995 and 1996, respectively.
Spotted knapweed adults developed in late-June 1995 and lateMay 1996 at Site 1. Most adults survived to produce seeds. Mortality was observed during September (20\%) 1995 and July (10\%) 1996. Spotted knapweed adults developed by late-June 1995 and late-May 1996 at site 2 . No adult mortality occurred during the growing season of 1995 , whereas $20 \%$ of the adult spotted knapweed population died during July and August in 1996.

The grass population at Site 1 began with 34 tillers $/ \mathrm{m}^{2}$ in April and peaked at 138 tillers $/ \mathrm{m}^{2}$ in October in 1995 (Fig. 4). In 1996, grass tiller numbers peaked in April at 243 tillers $/ \mathrm{m}^{2}$ and decreased to 121 tillers $/ \mathrm{m}^{2}$ in September. Grass tillers $/ \mathrm{m}^{2}$ in April, May, and June were greater than in July, August, and September. At Site 2, the grass population began with 582 tillers $/ \mathrm{m}^{2}$ in April and peaked at 890 tillers $/ \mathrm{m}^{2}$ in June 1995 (Fig. 4). In 1996, grass tiller numbers in April were 736 tillers $/ \mathrm{m}^{2}$ and peaked at 867 tillers $/ \mathrm{m}^{2}$ in May. Number of grass tillers decreased 442 tillers $/ \mathrm{m}^{2}$ between May and August.

\section{Sensitivity Analysis}

Maximum sensitivity values for spotted knapweed occurred with $10 \%$ reductions in the juvenile transition to adult, over-winter survivorship, juvenile and adult survivorship, and seed production in 1995 and 1996 at site 1 (Table 3) and site 2 (Table 4). A $10 \%$ reduction in seeds produced per adult decreased production by 106 


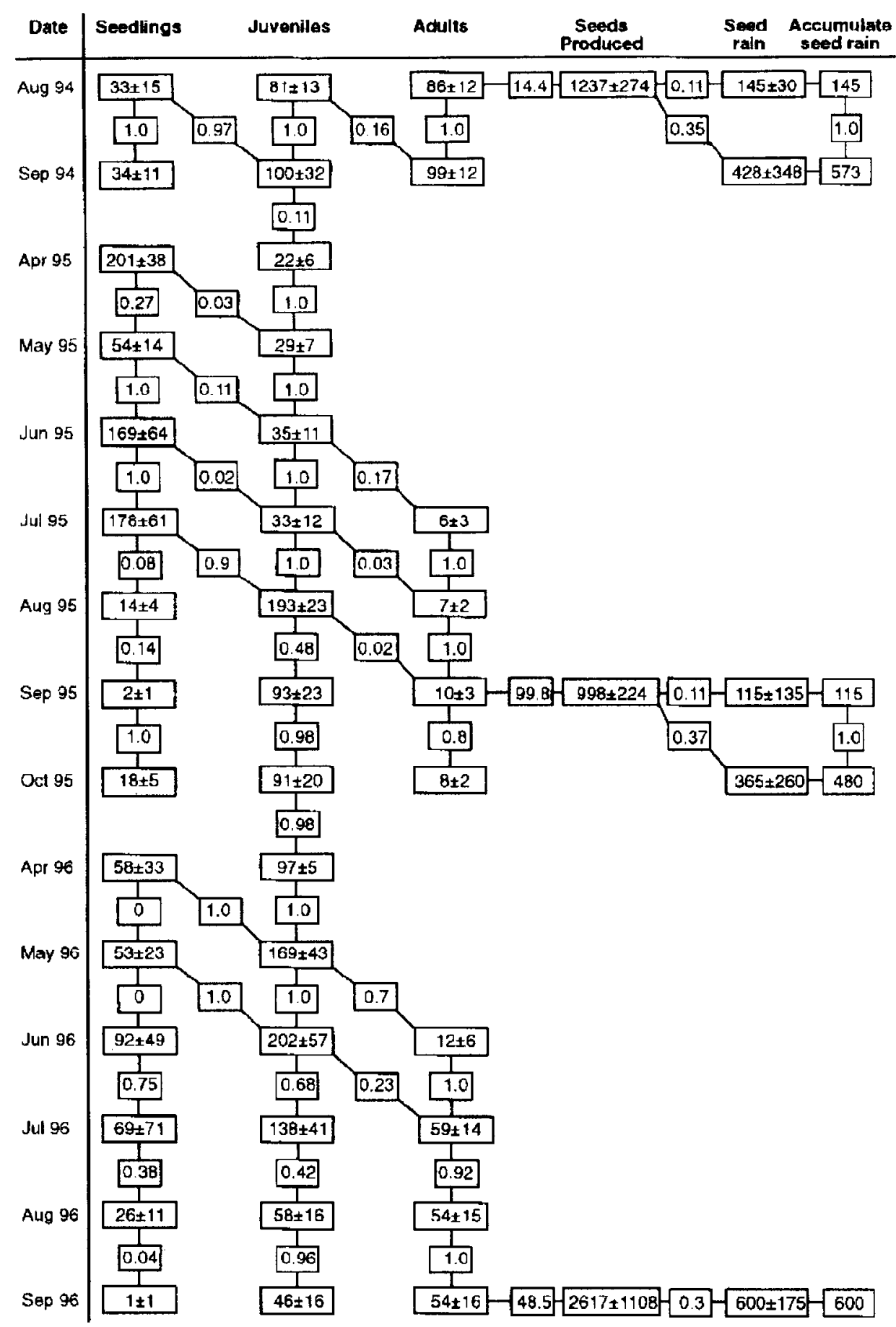

Fig. 2. Life history of spotted knapweed (August 1994-September 1996) at Site 1. Large boxes represent the means (n $=10)$ with $95 \%$ confidence values for each stage (population $/ \mathrm{m}^{2}$ ) at each sampling date. Small boxes indicate the population fraction transferred to the next sampling date (vertical) or life history stage (diagonal or horizontal lines).

seeds $/ \mathrm{m}^{2}$ in 1995 and 264 seeds $/ \mathrm{m}^{2}$ in 1996 at Site 1 , and by 707 seeds $/ \mathrm{m}^{2}$ in 1995 and 359 seeds $/ \mathrm{m}^{2}$ in 1996 at Site 2. Survivorship of adults was a critical stage for spotted knapweed populations at both sites. Seed production was decreased by $60 \mathrm{seeds} / \mathrm{m}^{2}$ in 1995 and 264 seeds $/ \mathrm{m}^{2}$ in 1996 at Site 1 and 673 seeds $/ \mathrm{m}^{2}$ in 1995 and 359 seeds/m $\mathrm{m}^{2}$ in 1996 at Site 2 when adult survivorship was reduced by $10 \%$. Early-season (June) transition from juvenile to adult was critical to spotted knapweed seed production in 1995 , whereas late-season transition (July) was critical in 1996. Juvenile survivorship was important in April and May 1995, and May and June 1996 at Site 1. At Site 2, juvenile survivorship was important in May and June in both years. Reductions in adult survivorship had low sensitivity values in June 1996 and high sensitivity values 


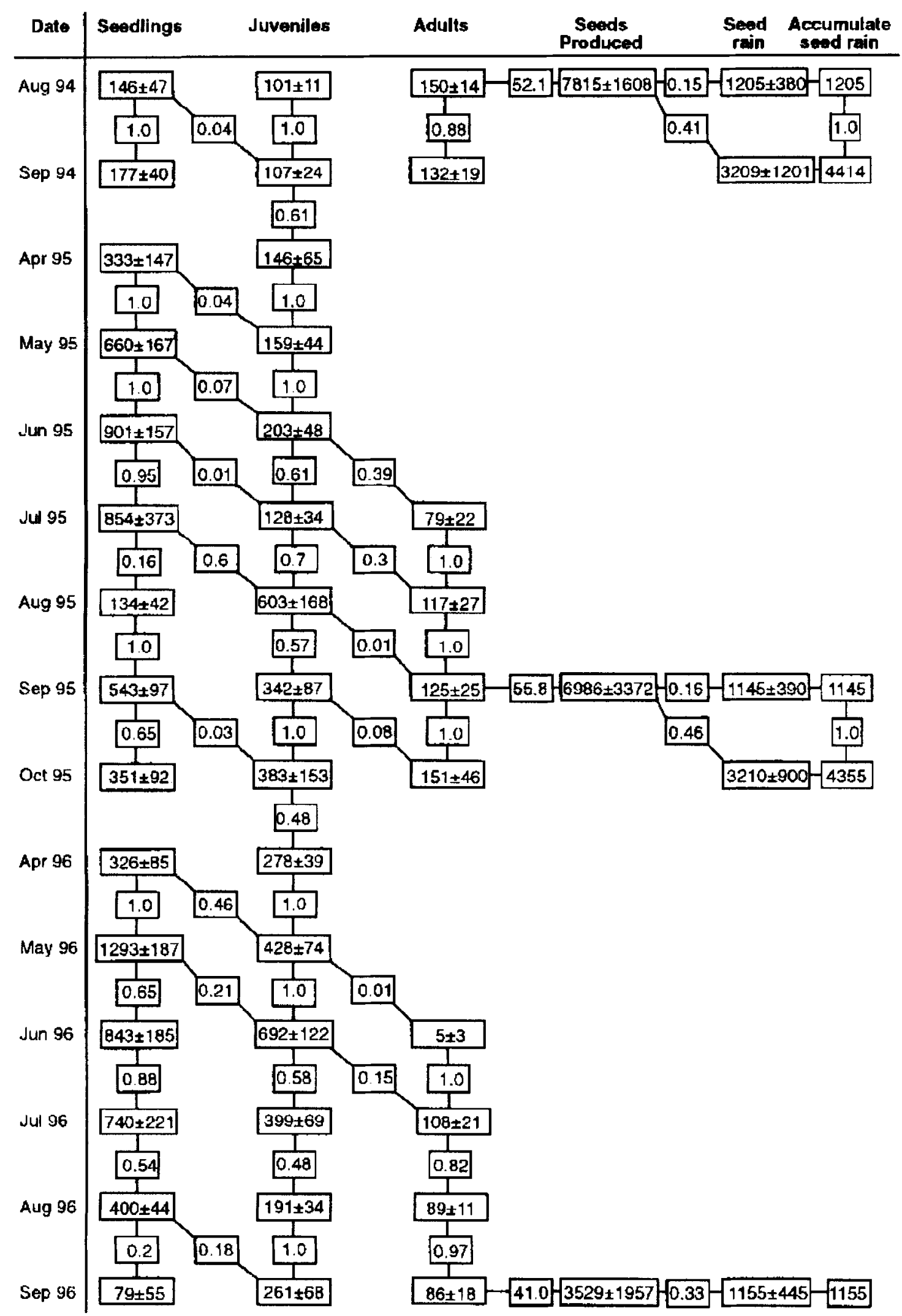

Fig. 3. Life history of spotted knapweed (August 1994-September 1996) at Site 2. Large boxes represent means $(\mathrm{n}=10)$ with $95 \%$ confidence values of life history stages (population $/ \mathrm{m}^{2}$ ) at each sampling date. Small boxes indicate the population fraction transferred to the next sampling date (vertical lines) or life history stage (horizontal and diagonal lines). 
Tuble 3. Sensitivity values (-10\%) calculated for spotted knapweed transitions at Site 1.

\begin{tabular}{|c|c|c|c|c|c|c|c|c|c|}
\hline Date & $\begin{array}{c}\text { Seed } \\
\text { rain }\end{array}$ & $\begin{array}{l}\text { Accumulated } \\
\text { seed rain }\end{array}$ & $\begin{array}{c}\text { Seedling } \\
\text { recruitment }\end{array}$ & $\begin{array}{c}\text { Seedling } \\
\text { survivorship }\end{array}$ & $\begin{array}{c}\text { Seeding } \\
\text { to juvenile }\end{array}$ & $\begin{array}{c}\text { Juvenile } \\
\text { survivorship }\end{array}$ & $\begin{array}{c}\text { Juvenile } \\
\text { to adult }\end{array}$ & $\begin{array}{c}\text { Adult } \\
\text { survivorship }\end{array}$ & $\begin{array}{c}\text { Seed } \\
\text { output }\end{array}$ \\
\hline $\begin{array}{l}1994 \\
\text { Aug. } \\
\text { Sep. }\end{array}$ & $\begin{array}{l}0.050 \\
0.158\end{array}$ & $\begin{array}{l}0.050 \\
0.158\end{array}$ & 0.282 & 0.057 & & 0.452 & & & \\
\hline $\begin{array}{l}1995 \\
\text { Apr. } \\
\text { May } \\
\text { Jun. } \\
\text { Jul. } \\
\text { Aug. }\end{array}$ & 0.051 & 0.051 & $\begin{array}{l}0.192 \\
0.015\end{array}$ & $\begin{array}{l}0.215 \\
0.091 \\
0.284\end{array}$ & $\begin{array}{l}0.124 \\
0.246 \\
0.299\end{array}$ & $\begin{array}{l}0.454 \\
0.578 \\
0.159 \\
0.093\end{array}$ & $\begin{array}{l}0.542 \\
0.096 \\
0.363\end{array}$ & $\begin{array}{l}0.542 \\
0.637\end{array}$ & 0.99 \\
\hline $\begin{array}{l}1996 \\
\text { Apr. } \\
\text { May } \\
\text { Jun. } \\
\text { Jul. } \\
\text { Aug. }\end{array}$ & 0.158 & 0.158 & $\begin{array}{l}0.206 \\
0.210\end{array}$ & $\begin{array}{l}0.09 \\
0\end{array}$ & $\begin{array}{l}0.296 \\
0.210\end{array}$ & $\begin{array}{l}0.493 \\
0.495 \\
0.604\end{array}$ & $\begin{array}{l}0.186 \\
0.814\end{array}$ & $\begin{array}{l}0.186 \\
1.0 \\
1.0\end{array}$ & 1.0 \\
\hline
\end{tabular}

in July and August in 1995 and 1996. Spotted knapweed seed and seedling stages and transitions had low $(<0.4)$ sensitivity values. Seed rain and accumulated seed rain had the lowest sensitivity values (with few exceptions).

\section{Simulation Model}

Simulations of average spotted knapweed populations began with a fall seed bank of 4,260 seeds $/ \mathrm{m}^{2}$ and 0 plants $/ \mathrm{m}^{2}$ (Fig. 5). Rosette and adult populations increased exponentially for 2 years before density-dependent regulation reduced population growth rate. Rosettes peaked at $218 / \mathrm{m}^{2}$ after 7 generations and adults peaked and stabilized at $174 / \mathrm{m}^{2}$ after 10 generations.

\section{Discussion}

Sensitivity analysis allows identification of critical life history stages, transitions and key processes associated with those transitions (Sagar and Mortimer 1976, Maxwell et al. 1988, Sheley and Larson 1994). Our analysis identified juvenile and adult survivorship, and the transition from juvenile to adult, as critical phases in the life history of spotted knapweed. Our results are similar to those of Sheley and Larson (1994) for yellow starthistle. Key processes associated with these stages are competition, growth rate, duration of growth, and reproductive allocation (Radosevich and Roush 1990). Understanding these processes appears essential to future regulation of species dominance and the establishment of functional communities on degraded grassland (MacMahon 1987, Allen 1988, Call and Roundy 1991, Sheley and Jacobs 1997). It is possible that desired plant communities could be designed to maximize niche occupation by establishing species which compete intensely, grow rapidly, and grow during much of the season (Sheley et al. 1996).

Throughout the study, variation between sites and among years was high. Higher precipitation and the northwestern aspect enhanced available soil moisture on site 2 which may have accounted for greater seed production and viable seedbank on that site than on Site 1 in 1994 and 1995. Shirman (1981) consistently found 2 to 10 times the seed production on sites that received nearly 2 times the annual precipitation as our study sites. Low seed production could also reflect the impact of seed head feeding insects on seed production. Shirman's (1981) data were collected from 1973 through 1976 , about the same time as initial

Table 4. Sensitivity values $(-10 \%)$ calculated for spotted knapweed transitions at Site 2.

\begin{tabular}{|c|c|c|c|c|c|c|c|c|c|}
\hline Date & $\begin{array}{l}\text { Seed } \\
\text { rain }\end{array}$ & $\begin{array}{l}\text { Accumulated } \\
\text { seed rain }\end{array}$ & $\begin{array}{l}\text { Seedling } \\
\text { recruitment }\end{array}$ & $\begin{array}{l}\text { Seedling } \\
\text { survivorship }\end{array}$ & $\begin{array}{l}\text { Seeding } \\
\text { to juvenile }\end{array}$ & $\begin{array}{c}\text { Juvenile } \\
\text { survivorship }\end{array}$ & $\begin{array}{l}\text { Juvenile } \\
\text { to adult }\end{array}$ & $\begin{array}{c}\text { Adult } \\
\text { survivorship }\end{array}$ & $\begin{array}{c}\text { Seed } \\
\text { output }\end{array}$ \\
\hline \multicolumn{10}{|l|}{1994} \\
\hline Aug. & 0.144 & 0.039 & & & & & & & \\
\hline Sep. & 0.105 & 0.105 & 0.090 & 0.100 & & 0.670 & & & \\
\hline \multicolumn{10}{|l|}{1995} \\
\hline Apr. & & & 0.039 & 0.127 & 0.130 & & & & \\
\hline May & & & 0.105 & 0.020 & 0.046 & 0.728 & & & \\
\hline Jun. & & & & & 0.041 & 0.304 & 0.634 & & \\
\hline Jul. & & & & & & 0.007 & 0.319 & 0.634 & \\
\hline Aug. & 0.073 & 0.073 & & & & & 0.048 & 0.953 & 1.001 \\
\hline \multicolumn{10}{|l|}{1996} \\
\hline Apr. & 0.204 & 0.204 & & 0.314 & & 0.409 & & & \\
\hline May & & & 0.277 & 0.093 & 0.221 & 0.409 & & & \\
\hline Jun. & & & & & 0.370 & 0.583 & 0.047 & 0.047 & \\
\hline Jul. & & & & & & & 0.953 & 1.0 & \\
\hline Aug. & & & & & & & & 1.0 & 1.0 \\
\hline
\end{tabular}




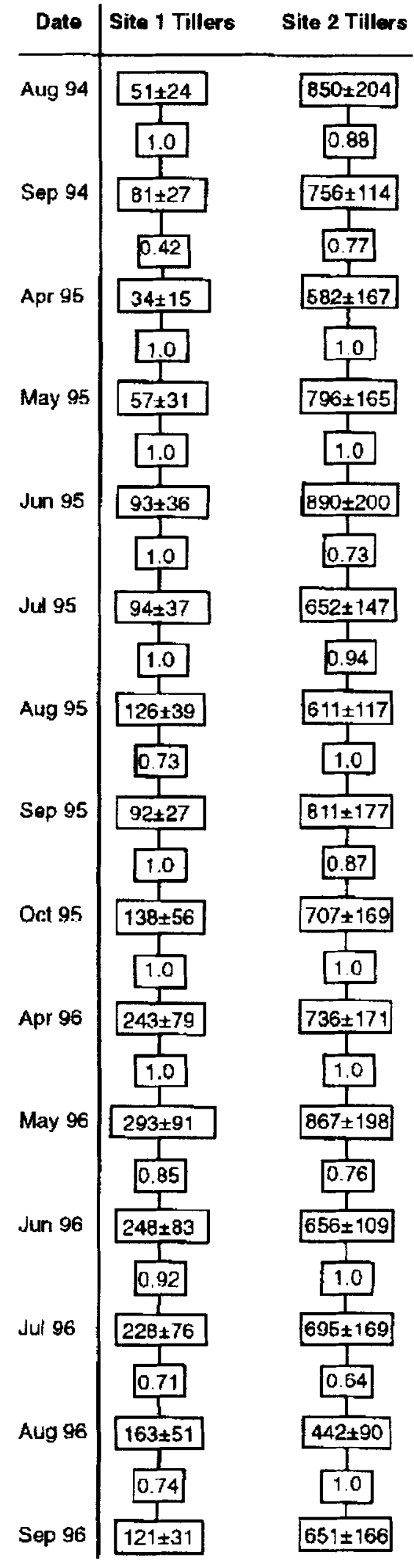

Fig. 4. Mean $(n=10)$ grass tillers $/ \mathrm{m}^{2}$ with $95 \%$ confidence value at each sampling date (August 1994-September 1996) for Site 1 and Site 2. Large boxes represent tiller population at a sampling date and small boxes represent the fraction of the population that transferred to the next sampling date.

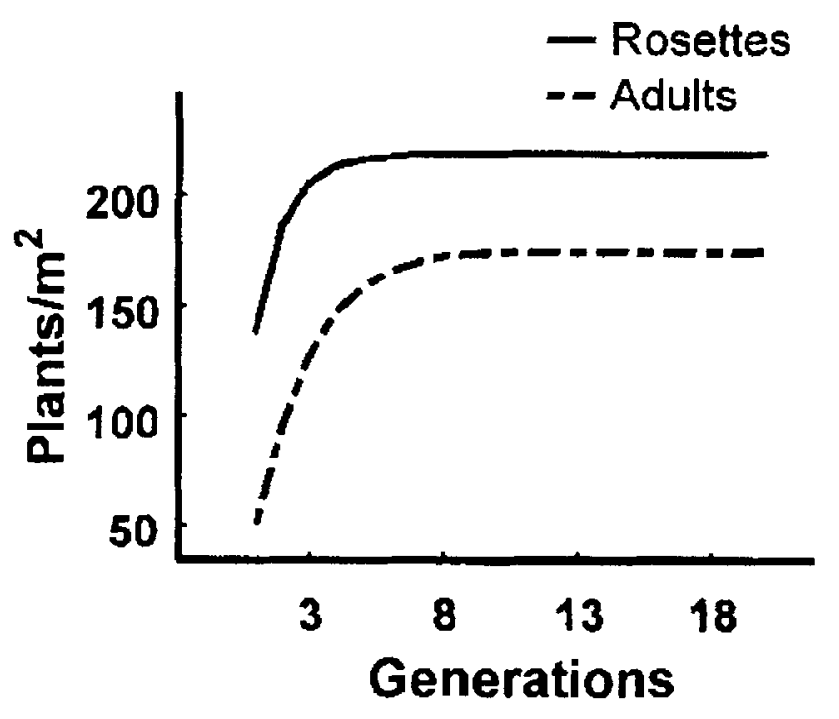

Fig. 5. Simulations of average spotted knapweed rosette and adult populations over 20 generations. Fall seed bank started with 4,260 seeds $/ \mathrm{m}^{2}$ and the rosette and adult populations started at 0 plants $/ \mathbf{m}^{2}$.

release of Urophora affinis (Frauenfeld) and U. quadrifasciata (Meigen) in Montana (Story et al. 1987). Larva of these insects were observed in $90 \%$ of the seed heads collected from our sites.

On the dryer site (Site 1), adult density appears sensitive to low spring precipitation. We speculate that juvenile mortality is enhanced because only dominant individuals possess enough root system for continued resource uptake and completion of their life cycle under dry conditions. These conclusions are consistent with those for yellow starthistle populations (Sheley and Larson 1994).

Plant population models that predict plant community composition based on the existing plant community and the weed management strategy are important tools for rangeland managers (Maxwell et al. 1988, Sheley et al. 1996). Our life history model provides baseline simulations needed for predicting spotted knapweed population dynamics (Figs 1 and 5). The use of models as decision-making tools will depend on understanding life histories of key species within the community, rather than simply that of spotted knapweed (Wiegand and Milton 1996). Future research needs to focus on collecting life history data for associated desirable species and incorporating that data into the model.

Models can be used to compile the various components of integrated management into a user-friendly predictive bioeconomic model that will aid in making decisions for managing spotted knapweed infested rangeland (Maxwell et al. 1988, Maxwell and Sheley 1997). The functions developed from all relevant research can be integrated into the bioeconomic model to predict and test the long-term effects of integrated spotted knapweed management on the plant community. Our results suggest that the high site to site and year to year variation in spotted knapweed population dynamics will make these models difficult to use as management tools. We believe probabilities of community dynamics derived from variation in data may be more useful in making weed management decisions. In this case, land managers can use the probability that a management program will result in a desired plant community as a basis for decision-making. 


\section{Literature Cited}

Allen, M.F. 1988. Belowground structure: A key reconstructing a productive arid ecosystem. p. 113-135. In: E.B. Allen (ed.), The reconstruction of disturbed arid lands:An ecological approach. Westview Press, Boulder Colo.

Barton, D.L., D.C. Thill, and B. Shafii. 1992. Integrated wild oat (Avena fatua) management affects spring barley. W. Soc. of Weed Sci., Proc.. 40:79.

Call, C.A. and R.A. Roundy. 1991. Perspectives and processes in revegetation of arid and semiarid rangelands. J. Range Manage. 44:543-549.

Davis, E.S., P.K. Fay, T.K. Chincoine, and C.A. Lacey. 1993. Persistence of spotted knapweed (Centaurea maculosa) seed in soil. Weed Sci. 41:57-61.

Dunan, C.M., F.D. Moore III, and P. Westra. 1994. A plant processeconomic model for wild oats management decisions in irrigated barley. Agr. Syst. 45:355-368.

Garbe D.F. 1970. Tetrazolium testing handbook. The tetrazolium testing committee of the association of official seed analysts. Lincoln. Nebr. p. $1-62$.

Griffith, D. and J. R. Lacey. 1991. Economic evaluation of spotted knapweed (Centaurea maculosa) control using picloram. J. Range Manage. 44:43-47.

Huenneke, L.A. and C. Graham. 1987. A new sticky trap for monitoring seed rain in grasslands. J. Range Manage. 40:370-372.

Lacey, J.R., C.B. Marlow, and J.R. Lane. 1989. Influence of spotted knapweed (Centaurea maculosa) on surface water runoff and sediment yield. Weed Technol. 3:627-631.

Lindquist, J.L., B.D. Maxwell, D.D. Buhler, and J.L. Gunsolus. 1995. Modeling the population dynamics and economics of velvetleaf (Abutilon theophrasti) control in a corn (Zea mays) soybean (Glucine max) rotation. Weed Sci. 43:269-275.

MacMahon, J.A. 1987. Disturbed lands and ecological theory: an essay about a mutualistic association. p 221-237. In: W.R. Jordan, M.E Gilpin, and J.D. Aber (eds), Restoration ecology: A synthetic approach to ccological rescarch. Cambridge Univ. Press, N.Y.

Maxwell, B.D. 1993. A bioeconomic model for determining long-term economic optimum wild oat management strategies in barley. W. Soc of Weed Sci., Proc. 46:77-78.

Maxwell, B.D. and R.L. Sheley. 1997. Noxious weed population dynamics education model. Weed Technol. 11:182-188.
Maxwell, B.D., M.V. Wilson, and S.R. Radosevich. 1988. Population modeling approach for evaluating leafy spurge (Euphorbia esula) development and control. Weed Technol. 2:132-138.

Muegller, W.F. and W.L. Stewart. 1980. Grassland and shrubland habitat types of western Montana. USDA Forest Serv. Gen. Tech. Rep. Int-66. $154 \mathrm{p}$.

NOAA 1994, 1995, and 1996. Climatological data annual summary Montana. Vols. 97, 98, and 99. Nat. Climatic Data Center. Asheville, N. C.

Radosevich, S.R. and M.L. Roush. 1990. The role of competition in agriculture, 341-363. In: Grace, J. and Tilman, D. (eds.). Perspectives on plant competition. Academic Press, London.

Sagar, G.R. and A.M. Mortimer. 1976. An approach to the study of the population dynamics of plants with special reference to weeds. Ann. Appl. Biol. 1:1-47.

Sheley, R.L., B.E. Olson, and L.L. Larson. 1997. Effect of weed seed rate and grass defoliation level on diffuse knapweed. J. Range Manage. $50: 39-43$.

Sheley, R.L. and J.S. Jacobs. 1997. "Acceptable" Levels of spotted knapweed (Centaurea maculosa) control. Weed Technol. 11:363-368.

Sheley, R.L. and L.L. Larson. 1994. Observation: Comparative livehistory of cheatgrass and yellow starthistle. J. Range Manage. 47:450-456.

Sheley, R.L., T.J. Svejcar, and B.D. Maxwell. 1996. A theoretical framework for developing successional weed management strategies on rangeland. Weed Technol. 10:766-773.

Sheley, R.L., J.S. Jacobs, and M.F. Carpinelli. 1998. Distribution, biology, and management of diffuse knapweed (Centaurea diffusa) and spotted knapweed (Centaurea moculosa). Weed Technol. 353-362.

Shirman, R. 1981. Seed production and spring seedling establishment of diffuse and spotted knapweed. J. Range Manage. 34:45-47.

Story, J.M., R.M. Nowierski, and K.W. Boffs. 1987. Distribution of Urophora affinis and $U$. quadrifasiciata, two flies introduced for biological control of spotted knapweed (Centaurea maculosa) in Montana. Weed Sci. 35:145-148.

Swinton, S.M. and R.P. King. 1994. A bioeconomic model for weed management in corn and soybean. Agr. Sys. 44:313-335.

Tyser, R.W. and C.H. Key. 1988. Spotted knapweed in natural area fescue grasslands: An ecological assessment. Northw. Sci. 62:981-987.

Watson, A.K. and A.J. Renney. 1974. The biology of Canadian weeds. 6. Centaurea diffusa and C. maculosa. Can. J. Plant Sci. 54:687-701.

Wiegand, T. and S.J. Milton. 1996. Vegetation change in semiarid communities. Vegetation. 125:169-183. 